\title{
Effect of Cytogenin, a Novel Immunomodulator, on Streptozotocin-induced Diabetes in Mice
}

\author{
Hiroyuki Kumagai, Kuniko Wakazono, Naoki Agata, Kunio Isshiki, Masaaki Ishizuka, \\ Daishiro Ikeda
}

Received: October 12, 2004 / Accepted: February 7, 2005

(C) Japan Antibiotics Research Association

\begin{abstract}
The anti-diabetic effect of cytogenin was examined using streptozotocin-induced diabetes in mice. Cytogenin suppressed not only the increase of plasma glucose level but also the body weight reduction in diabetic mice. Histological examination of the pancreas taken from diabetic mice given cytogenin showed that cytogenin decreased the number of macrophages infiltrated into islet of pancreas. Further, cytogenin suppressed the nitric oxide generation by macrophages treated with lipopolysaccharide through decreasing of inducible nitric oxide synthase expression. Cytogenin suppressed interleukin-6 expression by macrophage treated with LPS, suggesting that the antidiabetic activity of cytogenin might be partly attributed to the suppressive activity against nitric oxide generation.
\end{abstract}

Keywords cytogenin, streptozotocin, diabetes, macrophage, nitric oxide, inducible nitric oxide, interleukin-6

Cytogenin, a microbial product, was found to be an orally active antitumor agent against murine tumors [1 4]. It was also reported that cytogenin is effective in suppressing arthritis in murine models, affecting type II collageninduced arthritis, spontaneous polyarthritis, pristaneinduced arthritis and adjuvant-induced arthritis [5, 6]. In this report, we demonstrate that cytogenin has a potent anti- diabetic activity on streptozotocin (STZ)-induced diabetes in mice, which is thought to be an experimental model of insulin dependent diabetes mellitus (IDDM).

Diabetes was induced by STZ according to the methods reported by Nakamura et al. [7]. Briefly, ICR mice (7 weeks old, male) were given i.p. at $40 \mathrm{mg} / \mathrm{kg}$ of STZ for 5 successive days. Cytogenin at 10,30 and $100 \mathrm{mg} / \mathrm{kg} / \mathrm{day}$ was given p.o. for 18 days from the first injection of STZ. Mice ( 8 to 10 mice/experimental group) were housed and kept under a specific pathogen-free condition. Twice a week after STZ treatment, the body weight change of mice was measured. The induction of diabetes in mice treated with STZ was determined by glucose level of plasma and infiltration of macrophages around the islet of pancreas by histrogical examinations. Twice a week after STZ treatment, the glucose level in plasma of each mouse was determined by the glucose oxidase method (Glucose B test Wako, Wako Chemical Co., Japan). On day 32 after STZ treatment, the pancreas of each mouse was extirpated, fixed with $10 \%$ buffered formalin and then embedded in paraffin. The infiltration of macrophages into islets of Langerhans was determined microscopically with the hematoxylineosin stained sections. The degree of infiltration was scored as follows: grade 0, no infiltration; grade 1, slight infiltration; grade 2, moderate infiltration; grade 3, severe infiltration. Scores were calculated statistically using the Mann Whitney's $U$-test.

We examined the effect of cytogenin on inflammatory factors related to diabetes development such as nitric oxide
D. Ikeda (Corresponding author), H. Kumagai, M. Ishizuka: Numazu Bio-Medical Research Institute, Microbial Chemistry Research Foundation, 18-24 Miyamoto, Numazu, Shizuoka 4100301, Japan, E-mail: numazu@bikaken.or.jp
K. Wakazono, N. Agata, K. Isshiki: Bioresource Laboratories, Mercian Co. Ltd., 1808 Nakaizumi, Iwata, Shizuoka 438-0078, Japan 
(NOx), IL-1 and IL-6 produced by macrophages. CDF1 mice (7 weeks old, female, 5 mice/experimental group) were given i.p. at $50 \mathrm{mg} / \mathrm{kg}$ of Zymosan. From the next day, cytogenin was given p.o. for 10 successive days at 100 $\mathrm{mg} / \mathrm{kg}$. On day 12 after Zymosan treatment, peritoneal macrophages were collected and cultured with $0.5 \mu \mathrm{g} / \mathrm{ml}$ of LPS for 24 hours at $1 \times 10^{6}$ cells/ml in RPMI-1640 medium supplemented with $10 \%$ FCS. The culture supernatant was collected and the concentration of NOx was measured by the method reported by Keller et al. [8]. Briefly, $100 \mu \mathrm{l}$ of Griess reagent was mixed with $100 \mu$ l of the culture supernatant and incubated for 10 minutes at room temperature. The absorbance at $540 \mathrm{~nm}$ of the mixture was measured by a plate reader. NOx concentration was calculated from a $\mathrm{NaNO}_{2}$ standard curve. Inducible nitric oxide synthase (iNOS) in macrophages was detected by Western blotting. The macrophages cultured as mentioned above were lysed with a lysis buffer. Equal protein extracts were separated by SDS-PAGE and transferred onto PVDF membrane. Enhanced chemiluminescence was used to visualize the immunoblot signals of iNOS. Quantification of iNOS protein was performed by using the NIH image software.

CDF1 mice ( 7 weeks old, female, 5 mice/experimental group) were given p.o. at $100 \mathrm{mg} / \mathrm{kg}$ of cytogenin for 10 successive days. On day 11 after start of the administration, peritoneal macrophages were collected and cultured at $1 \times 10^{6}$ cells $/ \mathrm{ml}$ for 24 hours with $0.5 \mu \mathrm{g} / \mathrm{ml}$ of LPS. Concentrations of IL- 1 and -6 in the culture supernatant were measured with a commercial ELISA kit, respectively.

The body weight of mice was monitored in each experimental group. Treatment with STZ suppressed the normal increase of body weight of mice in comparison with non-treated mice. The suppression of body weight caused by STZ was inhibited by the administration of cytogenin at 30 and $100 \mathrm{mg} / \mathrm{kg}$ but not at $10 \mathrm{mg} / \mathrm{kg}$ (Fig. 1a).

The glucose level in plasma of mice treated with STZ was measured as an indicator for diabetes. Treatment with STZ increased the glucose level in plasma from day 12 through day 32 gradually. This increase in glucose level caused by STZ was significantly suppressed by cytogenin at 30 and $100 \mathrm{mg} / \mathrm{kg}$ (Fig. 1b). The glucose concentration on day 32 in each group was as follows: $174 \pm 6$ in non-treated mice, $542 \pm 68 \mathrm{mg} / \mathrm{dl}$ in mice treated with STZ alone, $532 \pm 51 \mathrm{mg} / \mathrm{dl}$ in mice given $10 \mathrm{mg} / \mathrm{kg}$ of cytogenin with STZ, $332 \pm 76 \mathrm{mg} / \mathrm{dl}$ in mice given $30 \mathrm{mg} / \mathrm{kg}$ of cytogenin with STZ, $312 \pm 64 \mathrm{mg} / \mathrm{dl}$ in mice given $100 \mathrm{mg} / \mathrm{kg}$ of cytogenin with STZ.

The infiltration of macrophages into islets of pancreas was examined (Fig. 2) and recorded as a score. As shown in Fig. 3, the scores in pancreas of mice given 30 and 100 (a)

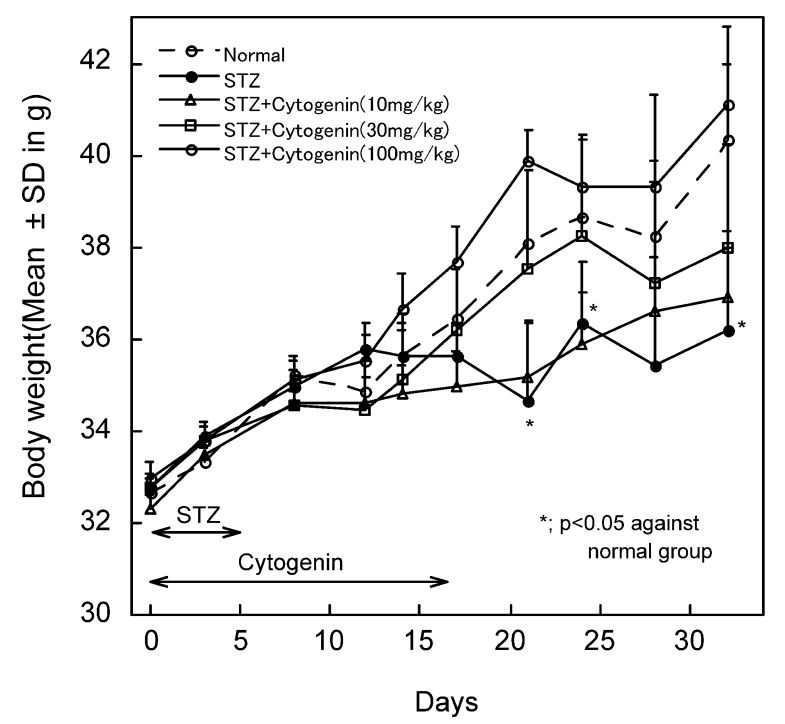

(b)

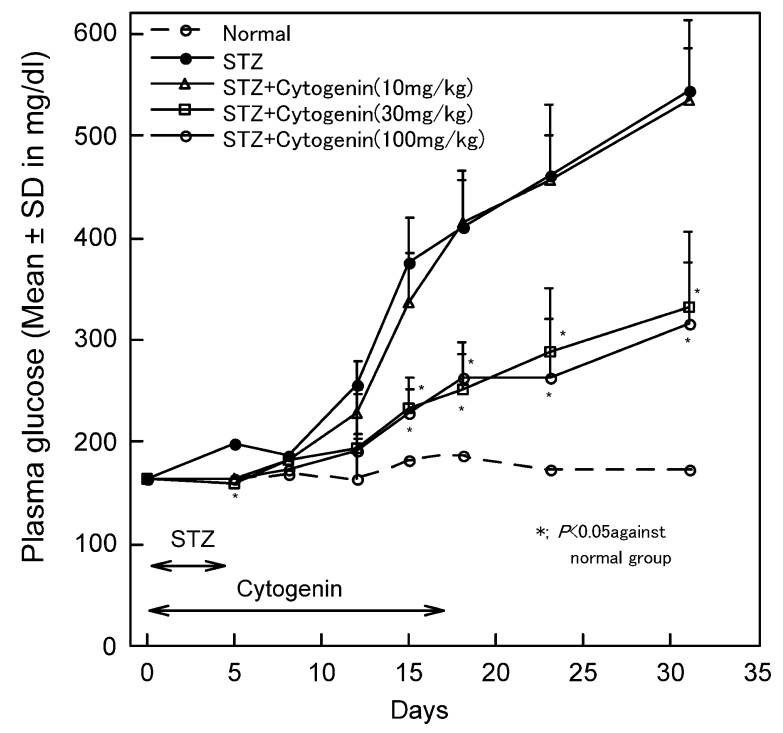

Fig. 1 Effect of cytogenin on body weight change (a) and plasma glucose level (b) in diabetic mice induced by STZ.

$\mathrm{mg} / \mathrm{kg}$ of cytogenin were significantly lower than that of mice treated with STZ alone (Fig. 3).

The NOx production of macrophages in culture was enhanced by elicitation with Zymosan and LPS-treatment from $2 \mathrm{nmol} / 10^{6}$ to $40 \mathrm{nmol} / 10^{6}$ cells. This increase in NOx production was significantly suppressed by cytogenin to $24 \mathrm{nmol} / 10^{6}$ cells (Fig. 4a). The production of iNOS in the macrophages was also suppressed by cytogenin (Fig. 4b).

The IL- 6 production of macrophages in culture was enhanced by LPS-treatment from $3 \mathrm{ng} / \mathrm{ml}$ to $42 \mathrm{ng} / \mathrm{ml}$. This increase in IL- 6 production by the macrophages was significantly suppressed by cytogenin from $42 \mathrm{ng} / \mathrm{ml}$ to 
Normal
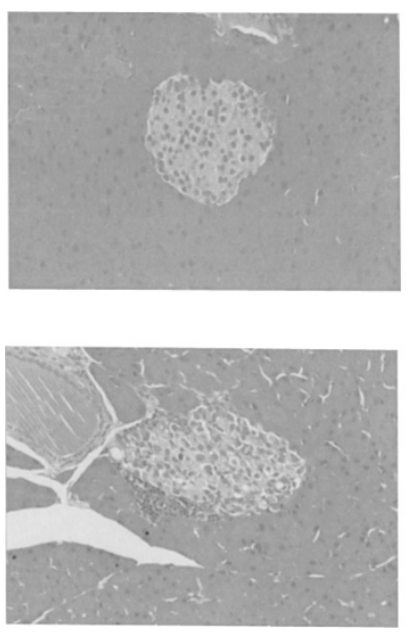

Cytogenin

(30 mg/kg)
STZ
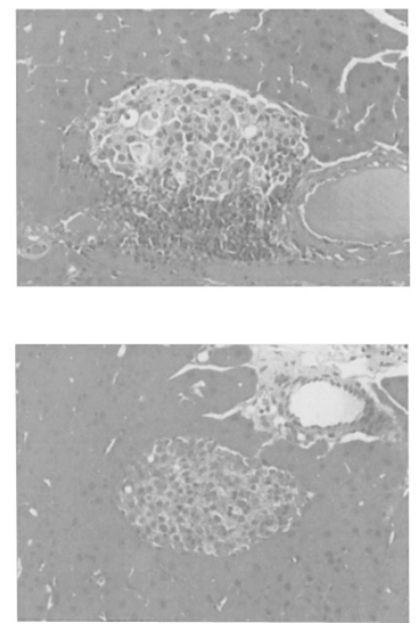

Cytogenin

$(100 \mathrm{mg} / \mathrm{kg})$

Fig. 2 Pathological findings of pancreas from mice given STZ and cytogenin.

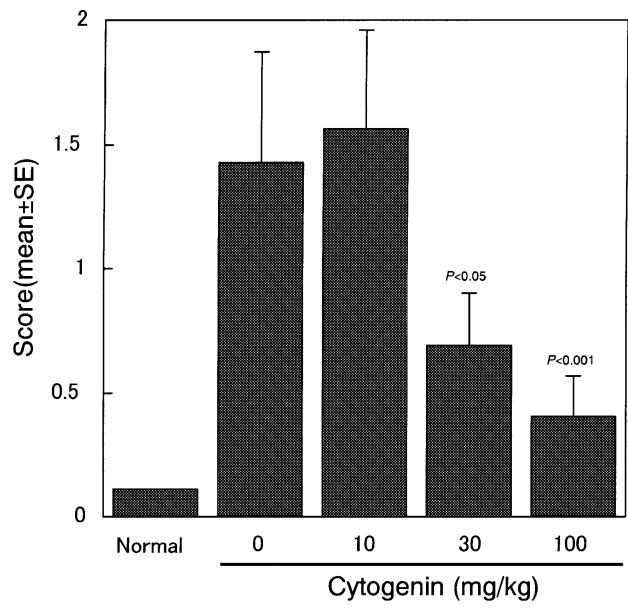

Fig. 3 Pathological changes of Langerhans' island taken from diabetic mice given cytogenin.

$17 \mathrm{ng} / \mathrm{ml}$ (Fig. 5). On the other hand, the IL-1 production by the macrophages in culture with LPS was not affected by cytogenin (data not shown).

STZ treated mice [7] and spontaneous onset mice [9, 10] have been developed for analyzing the onset mechanism of IDDM. The mechanism of diabetes development is still unclear, although STZ is known to induce autoimmunity to Langerhans' islet. It has been reported that NOx may mediate immunologically induced $\beta$-cell dysfunction in type I diabetes [11 13]. It is well known that NOx is

(a)
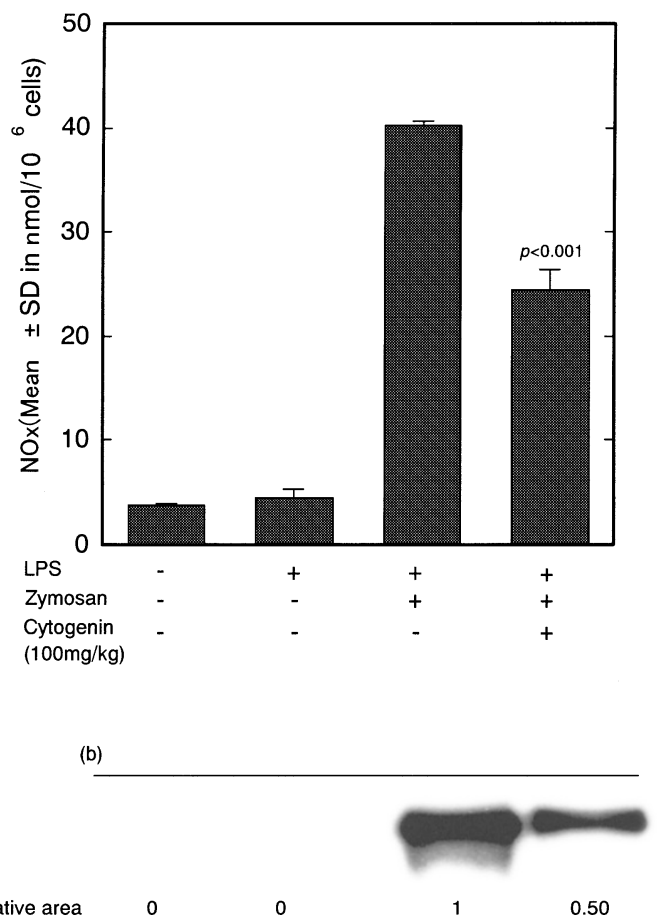

Fig. 4 NOx production (a) and iNOS production (b) by macrophages taken from mice given cytogenin.

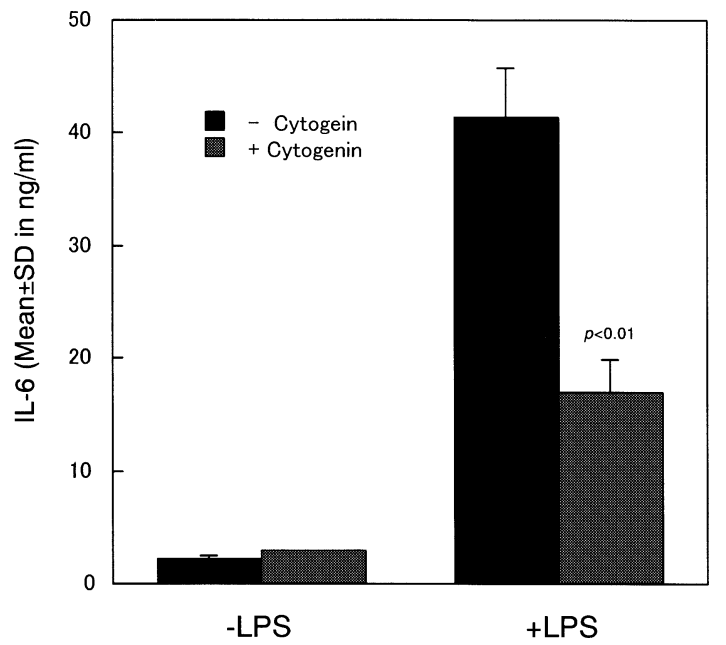

Fig. 5 IL-6 production by macrophages taken from mice given cytogenin.

generated by iNOS, which is produced by macrophages and $\beta$-cells in the pancreas, and the production of iNOS is stimulated by some inflammatory cytokines, such as IL-1, IL-6, TNF- $\alpha$ and IFN- $\gamma[14,15]$. In this context, we found that cytogenin suppressed not only NOx production but also iNOS and IL-6 expressions of LPS-treated 
macrophages in culture. The anti-diabetic action of cytogenin might be attributed by the suppression of NOx activity through modulation of activities of some inflammatory cytokines.

Although cytogenin suppressed the infiltration of macrophages into islet of pancreas dose dependently, plasma glucose level at $100 \mathrm{mg} / \mathrm{kg}$ was not normalized. Since cytogenin did not suppress the infiltration of macrophages completely in the score, cytogenin might not normalize the glucose level at the highest dose. The mechanism of the suppression of macrophage infiltration into islet is not clear. Cytogenin may also suppress the secretion of some chemokines such as IL-8 having chemotactic activity.

Since cytogenin is a compound with low toxicity and high bioavailability in experimental animals, it is a valuable lead compound in developing treatment of human type I diabetes.

\section{References}

1. Kumagai H, Masuda T, Osono M, Hattori S, Naganawa H, Sawa T, Hamada M, Ishizuka M, Takeuchi T. Cytogenin, a novel antitumor substance. J Antibiot 43: 1505-1507 (1990)

2. Kumagai H, Masuda T, Ishizuka M, Takeuchi T. Antitumor activity of cytogenin. J Antibiot 48: 175-178 (1995)

3. Kumagai H, Osono M, Iijima M, Sakashita M, Ishizuka M, Takeuchi T. Action of cytogenin on lymphoid cells and their cytokine production. J Antibiot 48: 317-320 (1995)

4. Kumagai H, Masuda T, Sakashita M, Ishizuka M, Takeuchi T. Modulation of macrophage activity on tumor bearing mice by cytogenin. J Antibiot 48: 321-325 (1995)

5. Hirano S, Wakazono K, Agata N, Mase T, Yamamoto R, Matsufuji M, Sakata N, Iguchi H, Tone H, Ishizuka M, Takeuchi T, Abe C. Effects of cytogenin, a novel antiarthritic agent, on type II collagen-induced arthritis in DBA/1 J mice and adjuvant arthritis in Lewis rats. Int $\mathrm{J}$ Tissue React 16: 155-162 (1994)

6. Abe C, Hirano S, Wakazono $\mathrm{K}$, Mase $\mathrm{T}$, Yamamoto $\mathrm{R}$, Matsufuji M, Sakata N, Agata N, Iguchi H, Ishizuka M, et al. Effects of cytogenin on spontaneous arthritis in MRL/1 mice and on pristane-induced arthritis (PIA) in DBA/1J mice. Int J Tissue React 17: 175-180 (1995)

7. Nakamura M, Nagafuchi S, Yamaguchi K, Takaki R. The role of thymic immunity and insulitis in the development of streptozocin-induced diabetes in mice. Diabetes 33: 894900 (1984)

8. Keller R, Keist R. Abilities of activated macrophages to manifest tumoricidal activity and to generate reactive nitrogen intermediates: a comparative study in vitro and ex vivo. Biochem Biophys Res Commun 164: 968-973 (1989)

9. Roth SI, Conaway HH, Sanders LL, Casali RE, Boyd AE. Spontaneous diabetes mellitus in the New Zealand white rabbit: preliminary morphologic characterization. Lab Invest 42: 571-579 (1980)

10. Sadelain MW, Qin HY, Lauzon J, Singh B. Prevention of type I diabetes in NOD mice by adjuvant immunotherapy. 39: 583-589 (1990)

11. Darville MI, Eizirik DL. Regulation by cytokines of the inducible nitric oxide synthase promoter in insulinproducing cells. Diabetologia 41: 1101-1108 (1998)

12. Flodstrom M, Tyrberg B, Eizirik DL, Sandler S. Reduced sensitivity of inducible nitric oxide synthase-deficient mice to multiple low-dose streptozotocin-induced diabetes. Diabetes 48: 706-713 (1999)

13. Kato Y, Miura Y, Yamamoto N, Ozaki N, Oiso Y. Suppressive effects of a selective inducible nitric oxide synthase (iNOS) inhibitor on pancreatic beta-cell dysfunction. Diabetologia 46: 1228-1233 (2003)

14. Tuna M, Polat S, Erman T, Ildan F, Gocer AI, Tuna N, Tamer L, Kaya M, Cetinalp E. Effect of anti-rat interleukin-6 antibody after spinal cord injury in the rat: inducible nitric oxide synthase expression, sodium- and potassium-activated, magnesium-dependent adenosine-5'-triphosphatase and superoxide dismutase activation, and ultrastructural changes. J Neurosurg 95: 64-73 (2001)

15. Wadt KA, Larsen CM, Andersen HU, Nielsen K, Karlsen AE, Mandrup-Poulsen T. Ciliary neurotrophic factor potentiates the beta-cell inhibitory effect of IL-1beta in rat pancreatic islets associated with increased nitric oxide synthesis and increased expression of inducible nitric oxide synthase. Diabetes 47: 1602-1608 (1998) 